\title{
Effects of NP-SR Fertilizer Composition and Water Logging on Soil Chemical Properties and N Fertilizer Efficiency in Paddy Field
}

DOI: $10.18196 /$ pt.v9i1.6434

\author{
Tiara Kartika Sari*, Muhammad Rif'an, Sakhidin \\ Postgraduate of Agronomic Study, Faculty of Agriculture, Universitas Jenderal Soedirman, \\ Jl. Dr. Soeparno No 61, Purwokerto, Jawa Tengah, 53123, Indonesia \\ *Corresponding author, email: tiarakartikasinulingga@gmail.com
}

\begin{abstract}
Rice is the primary food commodity in Indonesia. To increase the rice production, urea fertilizer has been excessively used, specifically on marginal land. However, it has no desired effect on the plant's Nitrogen uptake due to volatilization. Previous studies suggest the use of zeolite to be mixed with urea to reduce the volatilization rate. This study aimed to determine the effect of six NP-SR (Nitrogen Phosphorus Slow Release) fertilizer compositions (without NP-SR; 20.69-0; 19.7-5; 17.27-10; 15.9-15; and 18.94-20) on soil chemical properties, nitrogen efficiency, and paddy rice yield on Ultisols at three waterlogging levels $(0.5 \mathrm{~cm}, 3 \mathrm{~cm}$, and $5 \mathrm{~cm})$. The study was an experiment arranged in a Randomized Complete Block Design (RCBD) consisting of two factors, which were waterlogging levels and NP-SR fertilizer compositions. The results showed that waterlogging treatments significantly affected soil chemical properties in the initial vegetative and harvest phases. It can be concluded that the treatment of flooding (up to $3 \mathrm{~cm}$ ) and fertilizer (NP-SR of 15.90-15) application could significantly reduce the volatilization rate, increase the efficiency of $\mathrm{N}$ fertilizer, and increase rice yield.

Keywords: Nefficiency, Paddy, Ultisol, Zeolite
\end{abstract}

\section{ABSTRAK}

Beras masih menjadi komoditas pangan utama di Asia khususnya Indonesia. Penggunaan pupuk urea berlebih dalam upaya peningkatan produksi padi di lahan marginal tidak memberikan dampak yang efektif dalam pemanfaatan unsur nitrogen. Penggunaan zeolit sebagai bahan campuran dengan urea mampu menurunkan laju volatilisasi. Penelitian ini bertujuan untuk mengetahui pengaruh berbagai komposisi pupuk NP-SR terhadap sifat-sifat kimia tanah, efisiensi penggunaan nitrogen, serta hasil padi sawah pada ultisol pada berbagai ketinggian genangan. Rancangan penelitian disusun menggunakan Rancangan Acak Kelompok Lengkap (RAKL) yang terdiri atas dua faktor, yaitu tinggi genangan air (tiga aras) dan komposisi pupuk NP-SR (6 aras). Hasil penelitian menunjukkan bahwa perlakuan tinggi genangan air memberikan pengaruh yang nyata terhadap sifat kimia tanah yaitu pH pada fase vegetatif awal dan panen. Perlakuan penggenangan setinggi 3 cm dan aplikasi komposisi pupuk NP-SR 15,90-15 mampu menurunkan laju volatilisasi, meningkatkan efisiensi pupuk N dan meningkatkan hasil padi. Pemberian pupuk NP-SR dan perlakuan tinggi genangan air dapat memberikan respons terhadap N total tanah dan hasil tanaman padi.

Kata Kunci: Efisiensi N, Padi, Ultisol, Zeolit

\section{INTRODUCTION}

Rice is the main food commodity in supporting be achieved through the extensification of agriculthe needs of the Indonesian people (Amrullah, 2018). Rice plants (Oryza sativa L.) have become essential food crops, which are the staple food of more than half of the world's population. However, there have been some problems in efforts to increase rice crop production, including the increasing environmental damage and global climate change, limited infrastructure availability, and increasing conversion from agricultural land to non-agricultural land (Wahyuni et al., 2015). tural land outside Java. Nevertheless, islands over Indonesia apart from Java are dominated with acidic mineral soil, such as ultisol. Without proper management, this soil inhibits plant or food crops growth due to low $\mathrm{pH}$, low organic matter, low organism and biodiversity, and low productivity. Also, nutrients in ultisol are generally low due to intensive washing, while the low organic matter is caused by rapid decomposition and erosion (Syahputra et al., 2015). Thus, this type of soil should

The increase in national rice production could be treated with a large amount of fertilizer and 
ameliorant (Aainaa et al., 2014).

Syahputra et al. (2015) reported that the low total nitrogen $(\mathrm{N})$ content in the six of the Ultisol sub-groups (Typic Hapludults, Typic Paleudults, Psammentic Paleudults, Typic Plinthudults, Typic Ochraquults, and Typic Paleaquults) was due to the low content of soil organic carbon, loss due to washing, and evaporation. Plants absorb $\mathrm{N}$ in nitrate ions because there has been a change in the form of $\mathrm{NH}_{4}^{+}$to $\mathrm{NO}_{3}$. In flooded condition, plants absorb $\mathrm{N}$ in the form of $\mathrm{NH}_{4}^{+}$(Han et al., 2016). Nitrogen is a very mobile nutrient, rapidly experiencing volatilization, which releases $\mathrm{NH}_{3}$ into the air and loses $\mathrm{N}$ through leaching (Cai et al., 2002). Most $\mathrm{N}$ losses occur because of the volatilization of $\mathrm{NH}_{3}$ (Li et al., 2017). N losses range from 10 to 50\% of $\mathrm{N}$ fertilizer applied in rice cultivation (Coskun et al., 2017). $\mathrm{N}$ loss through the volatilization of $\mathrm{NH}_{3}$ is very significant, mainly if $\mathrm{N}$ fertilizer is applied through dispersion, which can reach 50\% (Sommer et al., 2004).

Nitrogen losses are also influenced by the rice fields' water condition, which will affect the oxidation and reduction processes in the paddy field, affecting the amount of $\mathrm{NH}_{3}$ volatile gas (Watanabe et al., 2009). In flooded condition, soil $\mathrm{pH}$ affects the volatilization process rate (Hadjowigeno \& Rayes, 2005) so that the management of flooding is expected to reduce $\mathrm{N}$ loss. The efficient use of fertilizers is an essential part of intensive rice farming systems. Chemical fertilizer use efficiency by farmers is currently less than 60\% (Sudarman 1990). Inefficient use of $\mathrm{N}$ fertilizers is caused by $\mathrm{N}$ loss from the soil system through evaporation in the form of ammonia, experiencing denitrification, erosion, and protection (Timilsena et al., 2015).

Increasing fertilizer efficiency can be done by improving cultivation and irrigation techniques, fertilization techniques, and fertilizer properties. Through these efforts, it is expected that the release of nutrients can be more regulated according to plants' needs so that nutrient losses outside the soil system can be reduced, and pollution to the environment can be decreased (Sastiono, 2004).

The use of slow-release and controlled urea fertilizers has been shown to reduce $\mathrm{N}$ loss in rice cultivation and improve rice yields (Ye et al., 2013; Li et al., 2018). One way to improve fertilizer efficiency is to mix fertilizer with zeolite (Suwardi, 2009). The use of natural zeolite can reduce the volatilization rate of $\mathrm{NH} 3$ from $\mathrm{N}$ fertilizer because this mineral has ample pore space to absorb and exchange cations (Van Straaten, 2002; Noori et al., 2006). This mechanism is the basis of this research in the use of zeolite as a mixture in urea.

Previous research showed that mixing urea with zeolite could reduce volatilization up to $6-44 \%$ compared to urea without zeolite (Ahmed et al., 2010; Palanivell et al., 2015). The use of natural nutrient-enriched zeolite $\mathrm{N}$ can continuously improve chemical properties, thereby improving soil fertility. Efforts to improve soil fertility can be achieved by providing NP-SR fertilizer so that it is expected to have an optimal influence on agricultural cultivation in acidic mineral soils. This study aimed to determine the effect of various NP-SR fertilizer compositions on soil chemical properties, nitrogen efficiency, and paddy rice yield on Ultisols at various waterlogging.

\section{MATERIALS AND METHODS}

Experimental design

The study consisted of two stages. The first stage was the acidulation of Natural Rocks Phosphate (NRP), NP-SR fertilizer production and greenhouses experiments. The second stage was testing NP-SR fertilizers on various compositions and various waterlogging levels using paddy plants (Inpari 32) on Ultisol's soil order.

The NP-SR fertilizer was made from urea, natural zeolite, natural phosphate rock, humid acid, and vertisol adhesive. The zeolit used has a $\mathrm{pH}$ 
$\mathrm{H}_{2} \mathrm{O}$ of 7.35 and a $\mathrm{pH} \mathrm{KCl}$ of 6.20 with a DHL value of $151 \mu \mathrm{S}$ per $\mathrm{cm}$. The $\mathrm{SiO}_{2}, \mathrm{Al}_{2} \mathrm{O}_{3}$ and $\mathrm{CaO}$ content of the zeolite were $75.8 \%, 15.4 \%$, and $2.45 \%$, respectively. Humic and fulfat acids are obtained from compost extracted with $\mathrm{NaOH}$, and then used for hydrothermal acidulation of natural phosphate rock.

The experiment of this study was arranged in a Randomized Complete Block Design (RCBD), consisting of two factors. The first factor was waterlogging level, consisting of W0 (0.5 cm depth), W1 (3 $\mathrm{cm})$, and W2 $(5 \mathrm{~cm})$. Meanwhile, the second factor was NP-SR fertilizer composition level, consisting of F0 (without NP-SR fertilizer application), F1 (provision of NP-SR fertilizer with a composition of $20.69 \%$ - 0\%), F2 (19.70\% - 5\%), F3 (17.27\% $10 \%)$, F4 (15.90\% - 15\%), and F5 (18.94\% - 20\%). Therefore, there were 18 treatment combinations with three replications in each treatment, resulting in 54 experimental units. The dose of fertilizer used was equivalent to $400 \mathrm{~kg} \mathrm{~N} / \mathrm{ha}$, which examined from April 2018 to February 2019 at the Screen House of the Faculty of Agriculture, Jenderal Soedirman University.

\section{Soil Analysis}

Soil sampling for analysis of soil chemical properties was carried out three times, 0 days after transplanting (DAT), the final vegetative phase of rice (75 DAT), and harvest (125 DAT). Soil samples with the Ultisol order were taken from Tanggeran, Banyumas, Central Java. Samples were taken at a depth of $0-30 \mathrm{~cm}$, dried, crushed, and filtered with a $2 \mathrm{~mm}$ sieve. Before treatment, soil samples were incubated for one week. Observation of $\mathrm{NH}_{3}$ gas was carried out every week during the experiment until harvest.

The measurement of $\mathrm{NH}_{3}$ gas evaporation (ammonia) was carried out by titrating the gas contained in $0.1 \mathrm{~N} \mathrm{H}_{2} \mathrm{SO}_{4}$ solution once a week start- ing from one week after transplanting until harvest. $\mathrm{N}$ was calculated using the following equations: 1. $\mathrm{N}$ absorbed $(\mathrm{mg} \mathrm{N} /$ chamber) $=$ (volume of $\mathrm{H}_{2} \mathrm{SO}_{4} 0.1 \mathrm{~N}$ container - volume of $\mathrm{NaOH} 0.1$ $\mathrm{N}$ used for titration) $\times 0.1 \times 14$

2. $\mathrm{N}$ volatilization $(\mathrm{mg} \mathrm{N} /$ chamber $)=\mathrm{N}$ volatilization in fertilizer - $\mathrm{N}$ volatilization in control

3. $\mathrm{N}$ volatilization $(\%)=(\mathrm{N}$ volatilization $(\mathrm{mg} \mathrm{N} /$ chamber))/( $\mathrm{N}$ in fertilizer (mg $\mathrm{N} /$ chamber $)$ ) $\mathrm{x}$ 100 (Wang et al., 2004)

4. $\mathrm{N}$-fertilizer efficiency $(\%)=100-\% \mathrm{~N}$ volatilizations

\section{Statistical Analysis}

The data were analyzed using ANOVA (Analysis of Variance), followed with Duncan's Multiple Range Test at 5\% to determine the differences between treatments using Excel spreadsheet and DSSTAT software. The treatment that showed the significant highest value based on DMRT was considered the best treatment.

Table 1. Chemical properties of Zeolites

\begin{tabular}{ll}
\hline Parameter & Average \\
\hline $\mathrm{pH} \mathrm{H} \mathrm{O}_{2}(1: 5)$ & 7.35 \\
$\mathrm{pH} \mathrm{KCl}(1: 5)$ & 6.20 \\
$\mathrm{EC}(1: 5)\left(\mu \mathrm{S} . \mathrm{cm}^{-1}\right)$ & 151 \\
$\mathrm{SiO}_{2}(\%)$ & 75.8 \\
$\mathrm{Al}_{2} \mathrm{O}_{3}(\%)$ & 15.4 \\
$\mathrm{CaO}(\%)$ & 2.45 \\
\hline
\end{tabular}

Remarks: Analysis conducted at the Laboratory of Geological Engineering, Jenderal Soedirman University.

\section{RESULTS AND DISCUSSION}

The primary component in NP-SR fertilizer is zeolite. Table 1 presents the results of the laboratory analysis of the chemical properties of zeolites. Zeolites used in this study had $\mathrm{pH} \mathrm{H}_{2} \mathrm{O}$ and $\mathrm{pH}$ $\mathrm{KCl}$ of 7.35 and 6.20 , respectively, with electrical conductivity (EC) value of $151 \mu \mathrm{S} \mathrm{cm} \mathrm{cm}^{-1}$, and the content of $\mathrm{SiO}_{2}, \mathrm{Al}_{2} \mathrm{O}_{3}$, and $\mathrm{CaO}$ of $75.8,15.4$, and $2.45 \%$, consecutively. The zeolite $\mathrm{pH}$ value in this study is high, which is similar to the $\mathrm{pH}$ value 
Table 2. The results of the analysis of variance on plant growth, soil chemical properties, plant $\mathrm{N}$ uptake, yields of rice, and $\mathrm{NH}_{3}$ evaporation as affected by the application of NP-SR fertilizer composition and waterlogging level

\begin{tabular}{|c|c|c|c|}
\hline \multirow{2}{*}{ Variable } & \multicolumn{3}{|c|}{ Treatment } \\
\hline & W & $\mathrm{F}$ & $W \times F$ \\
\hline \multicolumn{4}{|l|}{ Growth variables } \\
\hline Plant height & ns & ** & ns \\
\hline Leaf area & ** & ** & ns \\
\hline \multicolumn{4}{|l|}{ Soil chemical properties } \\
\hline $\mathrm{N}$-total 0 days after transplanting (DAT) & ns & * & ns \\
\hline N-total 75 DAT & ns & ns & * \\
\hline $\mathrm{N}$-total $125 \mathrm{DAT}$ & ns & ns & ** \\
\hline $\mathrm{pH} \mathrm{H}_{2} \mathrm{O} O \mathrm{DAT}$ & * & ns & ns \\
\hline $\mathrm{pH} \mathrm{H} \mathrm{H}_{2} \mathrm{O}$ DAT & ns & ns & ns \\
\hline $\mathrm{pH} \mathrm{H}_{2} \mathrm{O} 125$ DAT & * & ns & ns \\
\hline $\mathrm{pH} \mathrm{KCl} 0$ DAT & * & ** & ns \\
\hline pH KCl 75 DAT & ns & ns & ns \\
\hline $\mathrm{pH} \mathrm{KCl} 125$ DAT & ns & ns & ns \\
\hline EC 0 DAT & ns & ns & ns \\
\hline EC 75 DAT & ns & ns & ns \\
\hline EC 125 DAT & ns & * & ns \\
\hline \multicolumn{4}{|l|}{ Yields of rice } \\
\hline Percentage of filled grains & ns & ** & ** \\
\hline Percentage of empty grains & ns & $* *$ & ** \\
\hline \multicolumn{4}{|l|}{$\mathrm{NH}_{3}$ evaporation } \\
\hline $\mathrm{N}$ fertilizer efficiency & ** & $* *$ & ns \\
\hline
\end{tabular}

Remarks: $\mathrm{ns}=$ not significantly different, ${ }^{*}=$ significant, ${ }^{*}$ * $=$ very significant, $\mathrm{F}=\mathrm{NP}$-SR fertilizer composition, $\mathrm{W}=$ water logging level, $\mathrm{W} \times \mathrm{F}=$ interaction between water logging level and NP-SR fertilizer composition.

of the zeolite used by Bundan et al. (2011) with $\mathrm{pH}$ a water level of $3-10 \mathrm{~cm}$ did not affect the plant $\mathrm{H}_{2} \mathrm{O}$ of 7.90 . The silica content of zeolite used in height. There was no significant interaction effect this study (73.2\%) is almost the same as the zeolite of NP-SR fertilizer and watering on the growth from Gunung Kidul (Safrihatini, 2017). Various metal elements found in zeolite cause zeolite to be applied as a cation exchanger because zeolite contains various metal elements that could be exchanged with other desired metals.

component.

The treatment of NP-SR fertilizer composition can significantly increase plant height, and this indicates that plant growth is strongly influenced by the presence of nutrients (Kavoosi, 2007). The

The analysis of variance on the growth variables showed that the application of NP-SR fertilizer composition had a significant effect on the plant height and leaf area, while water logging level had a significant effect on the leaf area only (Table 2). A similar thing was reported by Juniadi et al. (2017) that rice planted in stagnant conditions with difference in the plant height in each treatment is influenced by the nutrient content contained in the soil. $\mathrm{N}$ nutrient, in this case, is closely related to photosynthesis. Nitrogen is useful for accelerating growth of vegetative parts of plants. $\mathrm{N}$ nutrient deficiency causes dwarf plants (small), small tillers, and narrow and pale-yellow leaves (Taiz \& Zeiger, 1991). 
The high level of waterlogging showed a very significant effect on the leaf area. The amount of nutrients absorbed by plant roots depends on the amount of moisture in the soil, determined by soil particles' ability to hold water and the roots' ability to absorb it. According to Gardner et al. (1991), lack of water in the vegetative phase causes leaves shrinkage, stem growth depression, and an increase in abscisic acid (ABA) stimulating stomatal closure, which results in reduced assimilation of $\mathrm{CO}_{2}$ to the leaves, thereby inhibiting the plant growth.

There was interaction effect of the combination of NP-SR fertilizer composition and the of water level on the total $\mathrm{N}$ content of the soil at 75 DAT and 125 DAT (Table 3). From the comparison of total soil $\mathrm{N}$ values before applying zeolite, which is $0.08 \%$ to $0.21 \%$, it can be concluded that the administration of NP-SR fertilizer composition can increase the total $\mathrm{N}$ value of the soil. This condition occurred because zeolite is one of the ingredients that can temporarily bind Nitrogen. Zeolites have a high cation exchange capacity (CEC) (between 120 $\left.-180 \mathrm{cmol}(+) \mathrm{kg}^{-1}\right)$, which is useful for adsorption, binding, and cation exchange (He et al., 2002).

Table 3 shows that at 75 DAT, the application of NP-SR fertilizer with a composition of 19.70-5 (F2) at the waterlogging of $0.5 \mathrm{~cm}$ increased the soil's total $\mathrm{N}$ content by $21.43 \%$ compared to without fertilization. The application of NP-SR fertilizer with a composition of 15.90-15 (F4) and 18.94-20 (F5) at the waterlogging of $0.5 \mathrm{~cm}$ gave the same results for the soil's total $\mathrm{N}$ content, which was $0.15 \%$, considered low. Meanwhile, the application of NP-SR fertilizer with a composition of 15.90-15 (F4) at the waterlogging level of $3 \mathrm{~cm}$ at 75 DAT increased the total $\mathrm{N}$ content of the soil by $50 \%$ compared to without fertilization. The soil's total $\mathrm{N}$ content is affected by waterlogging because water determines nutrient translocation related to oxidation and reduction reactions in solution.

The actual $\mathrm{pH}$ is generally higher than the potential $\mathrm{pH}$. Several processes in the soil are affected by soil reactions. The analysis of $\mathrm{pH} \mathrm{H}_{2} \mathrm{O}$, $\mathrm{pH} \mathrm{KCL}$, and soil EC at $\mathrm{O}$ days after transplanting

Table 3. Soil N-total (\%) as affected by the interaction between the application of NP-SR fertilizer composition and waterlogging level

\begin{tabular}{|c|c|c|c|c|c|}
\hline \multirow{2}{*}{ Observation } & \multirow{2}{*}{ Composition of NP-SR fertilizer (K) } & \multicolumn{3}{|c|}{ Waterlogging (W) } & \multirow{2}{*}{ Mean of $\mathrm{N}$-total (\%) } \\
\hline & & W0 $(0.5 \mathrm{~cm})$ & W1 $(3 \mathrm{~cm})$ & W2 $(5 \mathrm{~cm})$ & \\
\hline \multirow[t]{6}{*}{75 days after transplanting } & F0 (without fertilizer) & $0.13 \mathrm{~d} \mathrm{~B}$ & $0.14 \mathrm{fA}$ & $0.14 \mathrm{~d} A$ & 0.14 \\
\hline & F1 (20.69-0) & $0.13 d C$ & 0.15 e $B$ & $0.17 \mathrm{~b} \mathrm{~A}$ & 0.15 \\
\hline & F2 (19.70-5) & 0.17 a $\mathrm{A}$ & $0.16 \mathrm{~d} \mathrm{~B}$ & $0.17 \mathrm{~b} \mathrm{~A}$ & 0.16 \\
\hline & F3 (17.27-10) & 0.14 c C & $0.17 c B$ & 0.18 a A & 0.16 \\
\hline & F4 (15.90-15) & $0.15 b \mathrm{~b}$ & 0.21 a $\mathrm{A}$ & $0.17 \mathrm{~b} \mathrm{~B}$ & 0.17 \\
\hline & F5 (18.94-20) & $0.15 \mathrm{~b} \mathrm{~B}$ & $0.18 \mathrm{~b} \mathrm{~A}$ & $0.15 c B$ & 0.16 \\
\hline Mean of the N-total (\%) & & 0.16 & 0.18 & 0.17 & + \\
\hline \multirow[t]{6}{*}{125 days after transplanting } & F0 (without fertilizer) & $0.12 \mathrm{~d} \mathrm{~B}$ & $0.14 \mathrm{~d} A$ & $0.14 \mathrm{cA}$ & 0.15 \\
\hline & F1 (20.69-0) & $0.14 \mathrm{~b} \mathrm{~B}$ & $0.14 \mathrm{~d} \mathrm{~B}$ & 0.16 bc $A$ & 0.15 \\
\hline & F2 (19.70-5) & 0.17 a $\mathrm{A}$ & $0.16 c B$ & $0.17 \mathrm{~b} \mathrm{~A}$ & 0.16 \\
\hline & F3 (17.27-10) & 0.13 c C & $0.17 \mathrm{bc} B$ & $0.19 \mathrm{~b} \mathrm{~A}$ & 0.16 \\
\hline & F4 (15.90-15) & $0.14 \mathrm{bC}$ & $0.19 \mathrm{~b} \mathrm{~B}$ & 0.20 a A & 0.17 \\
\hline & F5 (18.94-20) & $0.14 \mathrm{~b} \mathrm{~B}$ & $0.20 \mathrm{a} \mathrm{A}$ & 0.20 a A & 0.16 \\
\hline Mean of the $\mathrm{N}$-total $(\%)$ & & 0.15 & 0.17 & 0.16 & + \\
\hline
\end{tabular}

Remarks: Values followed by the same lowercase letters in the same column are not significantly different according to Duncan's multiple range test at the level of $5 \%$. Values followed by the same uppercase letters in the same line are not significantly different according to Duncan's multiple range test at the level of $5 \%$. 
Table 4. Soil pH and electrical conductivity (EC) as affected by the application of NP-SR fertilizer composition and waterlogging level

\begin{tabular}{lccccccccc}
\hline \multirow{2}{*}{ Treatment } & \multicolumn{3}{c}{$\mathrm{pH} \mathrm{H}_{2} \mathrm{O}$} & \multicolumn{5}{c}{$\mathrm{EC}\left(\mu \mathrm{S} . \mathrm{cm}^{-1}\right)$} \\
\cline { 2 - 9 } & O DAT & 75 & 125 & 0 & 75 & 125 & 0 & 75 & 125 \\
\hline Waterlogging level & & & & & & & & & \\
W0 & $5.51 \mathrm{~b}$ & $6.44 \mathrm{a}$ & $6.50 \mathrm{a}$ & $4.58 \mathrm{a}$ & $5.61 \mathrm{a}$ & $5.82 \mathrm{a}$ & $108.11 \mathrm{a}$ & $121.16 \mathrm{a}$ & $136.72 \mathrm{a}$ \\
W1 & $5.80 \mathrm{a}$ & $6.44 \mathrm{a}$ & $6.42 \mathrm{a}$ & $4.45 \mathrm{~b}$ & $5.56 \mathrm{a}$ & $5.78 \mathrm{a}$ & $104.78 \mathrm{a}$ & $113.66 \mathrm{a}$ & $133.17 \mathrm{a}$ \\
W2 & $5.51 \mathrm{~b}$ & $6.26 \mathrm{a}$ & $6.12 \mathrm{~b}$ & $4.5 \mathrm{ab}$ & $5.57 \mathrm{a}$ & $5.84 \mathrm{a}$ & $104.17 \mathrm{a}$ & $111.11 \mathrm{a}$ & $129.78 \mathrm{a}$ \\
NP- SR fertilizer composition & & & & & & & & & \\
F0 & $5.54 \mathrm{a}$ & $6.35 \mathrm{a}$ & $6.23 \mathrm{a}$ & $4.26 \mathrm{~b}$ & $5.56 \mathrm{a}$ & $5.81 \mathrm{a}$ & $114.78 \mathrm{a}$ & $122.67 \mathrm{a}$ & $147 \mathrm{a}$ \\
F1 & $5.56 \mathrm{a}$ & $6.37 \mathrm{a}$ & $6.31 \mathrm{a}$ & $4.55 \mathrm{~b}$ & $5.57 \mathrm{a}$ & $5.88 \mathrm{a}$ & $113.89 \mathrm{a}$ & $119.89 \mathrm{a}$ & $143.77 \mathrm{a}$ \\
F2 & $5.69 \mathrm{a}$ & $6.47 \mathrm{a}$ & $6.45 \mathrm{a}$ & $4.59 \mathrm{a}$ & $5.62 \mathrm{a}$ & $5.78 \mathrm{a}$ & $99.00 \mathrm{a}$ & $104.00 \mathrm{a}$ & $113.78 \mathrm{~b}$ \\
F3 & $5.65 \mathrm{a}$ & $6.43 \mathrm{a}$ & $6.39 \mathrm{a}$ & $4.56 \mathrm{a}$ & $5.59 \mathrm{a}$ & $5.75 \mathrm{a}$ & $102.11 \mathrm{a}$ & $108.56 \mathrm{a}$ & $132.33 \mathrm{ab}$ \\
F4 & $5.58 \mathrm{a}$ & $6.37 \mathrm{a}$ & $6.42 \mathrm{a}$ & $4.55 \mathrm{a}$ & $5.63 \mathrm{a}$ & $5.83 \mathrm{a}$ & $94.67 \mathrm{a}$ & $96.89 \mathrm{a}$ & $117.66 \mathrm{~b}$ \\
F5 & $5.6 \mathrm{a}$ & $6.38 \mathrm{a}$ & $6.12 \mathrm{a}$ & $4.5 \mathrm{a}$ & $5.52 \mathrm{a}$ & $5.82 \mathrm{a}$ & $109.67 \mathrm{a}$ & $139.89 \mathrm{a}$ & $144.77 \mathrm{a}$ \\
\hline CV (\%) & 5.46 & 3.73 & 3.44 & 3.01 & 2.28 & 2.83 & 18.92 & 20.91 & 19.01 \\
\hline
\end{tabular}

Remarks: Values followed by the same lowercase letters in the same column are not significantly different according to Duncan's multiple range test at the level of $5 \%$. WO $=0.5 \mathrm{~cm}$ of water logging; $W 1=3 \mathrm{~cm} ; W 2=5 \mathrm{~cm}$. F0 = Control without fertilizer application; F1= NP-SR fertilizer with a composition of 20.69-0; F2 = 19.70-5; F3 = 17.27-10; F4 = 15.90-15; F5 = 18.94-20.

(DAT), 75 DAT, and 125 DAT is presented in vation, the waterlogging level of $5 \mathrm{~cm}$ resulted in Table 4. The waterlogging level of $3 \mathrm{~cm}$ increased the $\mathrm{pH} \mathrm{H} \mathrm{H}_{2} \mathrm{O}$ compared to the waterlogging level of $0.5 \mathrm{~cm}$ (Table 4). Table 4 shows that the waterlogging level at 0 DAT and 125 DAT affects the value of $\mathrm{pH} \mathrm{H}_{2} \mathrm{O}$. Meanwhile, the composition of NP-SR fertilizer does not affect the value of $\mathrm{pH}$ $\mathrm{H}_{2} \mathrm{O}$ in all observations. The increase in $\mathrm{pH}$ of the soil inundated is caused by reducing $\mathrm{Fe}_{3}+$ to $\mathrm{Fe}_{2}{ }^{+}$ when $\mathrm{OH}$-liberation occurs and consumption of $\mathrm{H}^{+}$(Bahmaniar \& Mirnia, 2002). Dissociation of $\mathrm{H}^{+}$from the edge of clay minerals and the surface of soil organic matter contributes to the soil's acidity. Besides, acid-neutral-base salts in soil solutions derived from mineral weathering, decomposition of organic matter, and fertilization will affect the soil $\mathrm{pH}$.

The $\mathrm{pH} \mathrm{H}_{2} \mathrm{O}$ had increased at 75 DAT in each waterlogging level treatment. The $\mathrm{pH}_{2} \mathrm{O}$ at $\mathrm{O}$ DAT classified as acidic in all waterlogging levels then as the plants grew, the $\mathrm{pH} \mathrm{H}_{2} \mathrm{O}$ became neutral. The changes in $\mathrm{pH}$ from acidic to neutral occurred from 0 DAT to 75 DAT. At each obserthe lowest value of $\mathrm{pH} \mathrm{H}_{2} \mathrm{O}$. At a depth of $5 \mathrm{~cm}$, $\mathrm{pH} \mathrm{H}_{2} \mathrm{O}$ also increased from 0 DAT to 75 DAT but then decreased at 125 DAT (6.2 to 6.0). The value of $\mathrm{pH} \mathrm{H}_{2} \mathrm{O}$ is strongly influenced by the level of waterlogging, which would determine ion solubility $\mathrm{H}^{+}$. In general, zeolite could increase soil $\mathrm{pH}$ because it has high alkalinity and contains alkaline cations, which can be released into the soil solution. Zeolite has a low base $\mathrm{pH}$ so that natural zeolite will neutralize the soil.

The value of $\mathrm{pH} \mathrm{KCl}$ increased at 75 DAT in each of waterlogging level. A cation exchange causes the increase in $\mathrm{pH} \mathrm{KCl}$, in which $\mathrm{K}^{+}$ions from $\mathrm{KCl}$ push $\mathrm{H}^{+}$ions in the absorption complex, increasing $\mathrm{H}^{+}$ions in the soil solution, then the $\mathrm{H}^{+}$ion will be absorbed by zeolite so that the value of $\mathrm{pH} \mathrm{KCl}$ will increase due to the decreasing $\mathrm{H}^{+}$ion in the soil solution. $\mathrm{KCl}$ can measure the activity of $\mathrm{H}^{+}$ions that are outside the soil solution. This is because $\mathrm{K}^{+}$ions in $\mathrm{KCl}$ can be exchanged with $\mathrm{H}^{+}$ions, while this does not apply to $\mathrm{H}_{2} \mathrm{O}$ (Sutanto, 2005). The value of soil EC ranges from $94.67 \mu \mathrm{S}$ 
Table 5. Effects of the interaction between the application of NP-SR fertilizer composition and waterlogging level on the percentage of filled grain and empty grain

\begin{tabular}{|c|c|c|c|c|c|}
\hline \multirow{2}{*}{ Observation } & \multirow{2}{*}{ Composition of NP-SR fertilizer (K) } & \multicolumn{3}{|c|}{ Waterlogging (W) } & \multirow{2}{*}{ Mean $(\%$} \\
\hline & & WO $(0.5 \mathrm{~cm})$ & W1 $(3 \mathrm{~cm})$ & $W 2(5 \mathrm{~cm})$ & \\
\hline \multirow[t]{6}{*}{75 days after transplanting } & F0 (without fertilizer) & $70.00 \mathrm{cA}$ & $63.49 \mathrm{~d} C$ & $65.73 \mathrm{~d} \mathrm{~B}$ & 66.40 \\
\hline & F1 (20.69-0) & 71.17 bc B & 73.07 c A & 72.76 c B & 72.33 \\
\hline & F2 (19.70-5) & $71.61 \mathrm{bc} C$ & 75.96 bc B & $77.77 \mathrm{bc} A$ & 75.11 \\
\hline & F3 (17.27-10) & $72.03 \mathrm{~b} \mathrm{C}$ & $78.21 \mathrm{~b} \mathrm{~A}$ & $76.67 \mathrm{bc} B$ & 75.63 \\
\hline & F4 (15.90-15) & 80.49 a C & 84.47 a $A$ & 82.94 a B & 82.63 \\
\hline & F5 (18.94-20) & $73.06 \mathrm{~b} \mathrm{C}$ & 76.09 b B & $79.45 \mathrm{~b} \mathrm{~A}$ & 76.20 \\
\hline Mean (\%) & & 73.06 & 75.25 & 75.88 & + \\
\hline \multirow[t]{6}{*}{125 days after transplanting } & F0 (without fertilizer) & 29.99 a C & 36.51 a $A$ & 34.27 a B & 33.59 \\
\hline & F1 (20.69-0) & $28.83 \mathrm{~b} \mathrm{~A}$ & $26.93 \mathrm{~b} \mathrm{~B}$ & 27.24 b B & 27.66 \\
\hline & F2 (19.70-5) & $28.39 \mathrm{~b} \mathrm{~A}$ & 24.04 b B & 22.23 c C & 24.88 \\
\hline & F3 (17.27-10) & $27.97 \mathrm{bc} A$ & $21.79 \mathrm{bc} C$ & 23.33 c B & 24.36 \\
\hline & F4 (15.90-15) & $19.51 \mathrm{cA}$ & 15.53 c C & $17.06 \mathrm{~d} B$ & 17.36 \\
\hline & F5 (18.94-20) & 26.94 bc A & 23.91 c B & $20.55 \mathrm{dc} C$ & 23.80 \\
\hline Mean (\%) & & 26.94 & 24.78 & 24.11 & + \\
\hline
\end{tabular}

Remarks: Values followed by the same lowercase letters in the same column are not significantly different according to Duncan's multiple range test at the level of $5 \%$. Values followed by the same uppercase letters in the same line are not significantly different according to Duncan's multiple range test at the level of $5 \%$. The density of rice grain is in $\%$.

$\mathrm{cm}^{-1}$ to $114.78 \mu \mathrm{S} \mathrm{cm} \mathrm{c}^{-1}$ (0 DAT), $96.89 \mu \mathrm{S} \mathrm{cm} \mathrm{cm}^{-1}$ to $139.89 \mu \mathrm{S} \mathrm{cm}^{-1}(75 \mathrm{DAT})$ and $117.66 \mu \mathrm{cm}^{-1}$ to 147 $\mu \mathrm{S} \mathrm{cm}{ }^{-1}$ (125 DAT). EC value tends to increase in line with the length of observation because during the planting period, natural zeolite from the soil sorption complex enters the soil to increase ionic strength and EC soil.

According to Table 5, the combination of NPSR fertilizer with a composition of 15.90-15 (F4) and waterlogging level of $0.5 \mathrm{~cm}, 3 \mathrm{~cm}$, and $5 \mathrm{~cm}$ increased rice grain density with the highest value compared to the other treatments at the same waterlogging level. The NP-SR fertilizer with a composition of 15.90-15 (F4) increased the percentage of rice grain to $82.63 \%$. Meanwhile, the combination of NP-SR fertilizer with a composition of 15.90-15 (F4) and waterlogging level of $3 \mathrm{~cm}$ (G1) increased the filled grain percentage up to $84.47 \%$. The number of granules in each panicle depends on the nitrogen supply at the beginning of the panicle growth. Rice yields are significantly associated with adequate plant nitrogen levels at both critical growth stages (Sanchez, 1992).

The efficiency of $\mathrm{N}$ fertilizer in this study was calculated from the volatilization amount, quantifying how much $\mathrm{N}$ evaporated and utilized by the plant. The NP-SR fertilizer composition and waterlogging level independently influence fertilizer efficiency. The waterlogging level of $3 \mathrm{~cm}$ and 5 $\mathrm{cm}$ can increase fertilizer efficiency $(21.16-21.74 \%)$ compared to treatment without water . Meanwhile, in the treatment of waterlogging level of $0.5 \mathrm{~cm}, \mathrm{~N}$ fertilization efficiency was only $62.32 \%$, and this might be due to the surface with shallow water, which quickly dries so that the condition is hotter than the other waterlogging.

NP-SR fertilizer composition affects the efficiency of $\mathrm{N}$ fertilizer. Table 6 shows that the NP-SR fertilizer composition F4 resulted in the highest efficiency of $\mathrm{N}$ fertilizer, reaching $75.99 \%$, followed by F1, F2, F3, and F5, which showed N fertilizer efficiency of 73.94\%, 72.94\%, 72.66\%and 
Table 6. Evaporation of $\mathrm{NH}_{3}$ and fertilizer efficiency as affected by the application of NP-SR fertilizer composition and waterlogging level

\begin{tabular}{lc}
\hline Treatment & Fertilizer efficiency (\%) \\
\hline Waterlogging & \\
W0 & $62.32 \mathrm{~b}$ \\
W1 & $75.57 \mathrm{a}$ \\
W2 & $75.87 \mathrm{a}$ \\
NP-SR fertilizer composition & \\
F0 & $99.82 \mathrm{a}$ \\
F1 & $73.00 \mathrm{bc}$ \\
F2 & $72.95 \mathrm{c}$ \\
F3 & $72.66 \mathrm{~d}$ \\
F4 & $73.95 \mathrm{~b}$ \\
F5 & $72.17 \mathrm{e}$ \\
\hline CV (\%) & 4.62 \\
\hline
\end{tabular}

Remarks: Values followed by the same lowercase letters in the same column are not significantly different according to Duncan's multiple range test at the level of $5 \%$. WO $=0.5 \mathrm{~cm}$ of waterlogging; $\mathrm{W} 1=3$ $\mathrm{cm} ; \mathrm{W} 2=5 \mathrm{~cm}$. F0 = Control without fertilizer application; F1 = NP-SR fertilizer with a composition of 20.69-0; F2 = 19.70-5; F3 = 17.27-10; $\mathrm{F} 4=15.90-15 ; \mathrm{F} 5=18.94-20$.

$72.17 \%$, respectively, meaning that only around $25 \% \mathrm{~N}$ was lost due to volatilization. Omar et al. (2010) reported that a zeolite mixture significantly minimized volatile ammonia between 40 and 50\% compared to urea without additives. Zhang et al. (2012) reported that rice cultivation in Asia could only achieve $\mathrm{N}$-use efficiency ranging from only $20-35 \%$ and challenging to reach $40 \%$.

The results indicated that $\mathrm{N}$ loss through volatilization in the administration of NP-SR fertilizer composition ranged from $24.3 \%-27.83 \%$ compared to urea treatment alone, reaching $70 \%$. The same thing was revealed by Ahmed et al. (2010), mentioning that zeolite could minimize ammonia loss due to zeolites' ability to absorb essential nutrients such as ammonium and potassium. Lija et al. (2012) reported that the soil treatment (control) did not show any loss of $\mathrm{NH}_{3}$, and treatment with the addition of zeolite at a specific dose was significantly lower in the loss of $\mathrm{NH}_{3}$ than in the treatment of urea without zeolite.
Omar et al. (2010) reported that zeolite mixtures significantly minimized volatile ammonia between 40 and 50\% compared to urea without additives. Also, the treatment significantly increased available nitrogen nitrate compared to urea without additives. Volatilization of ammonia from urea could be significantly reduced in flooded conditions so that $\mathrm{N}$ efficiency increased.

During stagnant conditions, $\mathrm{N}$ loss occurs through evaporation, denitrification, and washing (Rahmawati 2013). Slowly released N fertilizers can reduce $\mathrm{N}$ loss and meet $\mathrm{N}$ needs in plants, as well as increase crop yields and fertilizer efficiency (Yi et al., 2006; Zhang et al., 2010; Gui-Hua et al., 2011; Chen et al., 2017). Slowly-released $\mathrm{N}$ fertilizers have a release speed that is almost equal to the $\mathrm{N}$ requirement absorbed by the plant, resulting in a reduction in inorganic $\mathrm{N}$ accumulation in the soil and minimizing the risk of $\mathrm{N}$ loss among $\mathrm{N}$ uptake by planting with $\mathrm{N}$ availability. $\mathrm{N}$ in the plant can be increased by providing balanced $\mathrm{N}, \mathrm{P}$, and $\mathrm{K}$ fertilizers (Bijay-Singh et al., 1995).

\section{CONCLUSION}

The level of waterlogging on a rice paddy field significantly affects the soil chemical properties, specifically the soil $\mathrm{pH}$ at the initial vegetative phase and harvest. The waterlogging level of $3-\mathrm{cm}$ and the application of NP-SR fertilizer with a composition of 15.90-15 can reduce the volatilization rate, increase $\mathrm{N}$ fertilizer efficiency, and increase rice yield.

\section{ACKNOWLEDGMENT}

The authors would like to thank the Rector of the Universitas Jenderal Soedirman for the 2018 Competency Research Grant (Hibah Penelitian Kompetensi TA 2018), as well as the Head of Research and Service Agency (LPPM) of the Universitas Jenderal Soedirman, all staff, and all colleagues for the contribution to this research. 


\section{REFERENCES}

Aainaa, H., Ahmed, O. H., Kasim, S., Majid, N. M. (2014). Use of clinoptilolite zeolite to reduce Christmas island rock phosphate use in Zea mays cultivation on an acid soil. International Journal of Soil Science, 9(2), 66-66. doi: 10.3923/ijss.2014.55.66.

Aainaa, H, Ahmed, O. H., Majid, N. M. (2018). Effect of clinoptilolite zeolite on phosphorus dynamics and yield of Zea mays cultivated on an acid soil. Plos One, 13(9). doi:10.1371/journal. pone. 0204401.

Ahmed, O. H., Braine, C. H., Muhamad, A. M. (2010). Minimizing ammonia loss from urea through mixing with zeolite and acid sulphate soil. Int. J. Phys. Sci., 5 (14), 2198-2202.

Bahmaniar, M. A., Mirnia, S. K. (2002). The Effect of different waterlogging Periods on Morphology and Clay Minerology of Paddy Soils. Paper presented at Proceedings of 17th World Congress of Soil Science, Bangkok, Thailand (pp. 15).

Bijay-Singh, Yadvinder-Singh, Sekhon, G. S. (1995). Fertilizer-N use efficiency and nitrate pollution of groundwater in developing countries. Journal of Contaminant Hydrology, 20, 167-184. doi: 10.1016/0169-7722(95)00067-4.

Bundan, L., Majid, N. M., Ahmed, O. H., Jiwan, M., Kundat, F. R. (2011). Ammonia volatilization from urea at different levels of zeolite Int. Journal of the Physical Science, 6(34), 7717-7720. doi: 10.5897/IJPS11.592.

Cai, G. X., Chen, D. L., Ding, H., Pacholski, A., Fan, X. H., Zhu, Z. L. (2002). Nitrogen losses from fertilizers applied to maize, wheat and rice in the North China. Plan. Nutr. Cycl. Agroecosyst, 63 187-195.

Chen, T. T., Xia, G. M., Wu, Q., Zheng, J. L., Jin, Y., Sun, D. H., Wang, S. C., Chi, D. C. (2017). The influence of zeolite amendment on yield performance, quality characteristics, and nitrogen use efficiency of paddy rice. Crop Sci., 57, 2777.

Coskun, D., Britto, D. T., Shi, W., Kronzucker, H. J. (2017). Nitrogen transformations in modern agriculture and the role of biological nitrification inhibition. Nat. Plants, 3(6), 17074.

Gardner, F. P., Pearce, R. B., Mitchell, R. L. (1990). Physiology of Crop Plant. lowa, US: lowa State Univ Pr. Ames.

Gui-Hua, Lin-Ping, Z., Shu-Xiang, Y., Hosen, Y., Yagi, K. (2011). Recovery and Leaching of $15 \mathrm{~N}$-Labeled Coated Urea in a Lysimeter System in the North China Plain. Pedosphere, 21(6), 763-772. doi: 10.1016/S1002-0160(11)60180-X.

Han, M., Clippeleir, D., Omari, A. A., Wett, B., Vlaeminck, S. E., Bott, C., Murthy, S. (2016). Impact of carbon to nitrogen ratio and aeration regime on mainstream deammonification. Water Science and Technology, 74(2), 375-384. doi: 10.2166/wst.2016.202.

Hardjowigeno, H. S., Rayes, M. L. (2005). Tanah Sawah. Malang, Indonesia: Bayumedia.

He, Z. L., Calvert, D. V., Alva, A. K., Li, Y. C., Banks, D. J. (2002). Clinoptilolite zeolite and cellulose amendments to reduce ammonia volatilization in a calcareous sandy soil. Plant and Soil, 247, 253-260.

Junaidi, R. \& Burhanuddin. (2015). Pengaturan Pemberian Air pada Sawah Bukaan Baru yang Memiliki Kandungan Fe Sangat Tinggi. Padang, Indonesia: Universitas Andalas (Skripsi).
Kavoosi, M. (2007). Effects of zeolite application on rice yield, nitrogen recovery, and nitrogen use efficiency. Communications in Soil Science and Plant Analysis, 38, 69-76. doi: 10.1080/ 00103620601093652.

Li, P. F., Lu, J. W., Wang, Y., Wang, S., Hussain, S., Ren, T., Cong, R., Li, X. K. (2018). Nitrogen losses, use efficiency, and productivity of early rice under controlled-release urea. Agric. Ecosyst. Environ., 251, 78-87.

Lija, W. B., Ahmed, O. H., Kasim, S. (2012). Reducing ammonia volatilization from compound fertilizers amended with zeolite. African Journal Biotechnology, 11(74), 13903-13906. doi: 10.5897/AJB12.1236.

Noori, M., Zendehdel, M., Ahmadi, A. (2006). Using natural zeolite for improvement of soil salinity and crop yield. Toxicol. Environ. Chem. Rev., 88(1), 77-84.

Omar, L. O., Ahmed, O. H., Muhammad, A. M. (2010). Minimizing ammonia volatilization in waterlogged soils through mixing of urea with zeolite and sago waste water. Int. J. Phys. Sci., 5(14), 2193-2197.

Palanivell, P., Ahmed, O. H., Susilawati, K., Majid, N. M. A. (2015). Mitigating ammonia volatilization from urea in waterlogged condition using clinoptilolite zeolite. Int. J. Agric. Biol., 17(1), 149-155.

Rachmawati, D. \& Retnaningrum, E. (2013). Pengaruh dan Tinggi dan Lama Penggenangan terhadap Pertumbuhan Padi Kultivar Sintanur dan Dinamika Populasi Rhizobakteri Pemfiksasi Nitrogen Non Simbiosis. Jurnal IImu-IImu Hayati dan Fisik, 15(2), 117-125.

Sastiono, A. (2004). Pemanfaatan Zeolit di Bidang Pertanian. Jurnal Zeolit Indonesia, 3(1), 36-41.

Safrihatini, W. (2017). Potensi zeolit alam gunung kidul teraktivasi sebagai media adsorben pewarna tekstil. Arena Tekstil, 32(1), 17-24.

Sommer, S. G., Schjoerring, J. K., Denmead, O. T. (2004). Ammonia emission from mineral fertilizers and fertilized crops. Adv. Agron., 82, 557-622.

Sudarman, S. (1990). Efisiensi Pemupukan pada Padi dan Palawija. Bogor, Indonesia: Laporan khusus Puslitbangtan.

Sutanto, R. (2005). Dasar-Dasar Ilmu Tanah Konsep dan Kenyataan. Yogyakarta, Indonesia: Kanisius.

Syahputra, E., Fauzi, R. (2015). Karakteristik Sifat Kimia Sub Grup Tanah Ultisol di Beberapa Wilayah Sumatera Utara. Jurnal Agroekoteknologi, 4(1), 1796-1803.

Taiz, L. \& Zeiger, E. (1991). Plant Physiology: Mineral Nutrition. Redwood: The Benyamin Cumming Publishing Co., Inc.

Timilsena, T. P., Adhikari, R., Casey, P., Muster, T., Gill, H., Adhikari, B. (2015). Enhanced efficiency fertilizers: a review of formulation and nutrient release patterns. Journal of the Science of Food and Agriculture, 95, 1131-1142. doi: 10.1002/jsfa.6812.

Van Straaten. (2002). Rocks for Crops. Agrominerals of Sub Saharan Africa. Canada: Department of Land Resources Science. University of Guelph.

Wahyuni, E. S., Saiful, \& Pudjiastuti, E. W. (2015). Pengaruh penggunaan pupuk NPK terhadap produksi padi (Oryza sativa L.) varietas Ciherang. Jurnal Bioshell, 1(4), 233-242. 
Wang, Z. H., Liu, X. J., Ju, X. T., Zhang, F. S., Malhi, S. S. (2004). Ammonia volatilization loss from surface-broadcast urea: comparison of vented and closed chamber methods and loss in winter wheat-summer Maize rotation in north china plain. Communications in Soil Science and Plant Analysis, 35 (19-20), 2917-2939. doi: 10.1081/LCSS-200036499.

Watanabe, T., Son, T. T., Hung, N. N., Truong, N. V., Giau, T. Q., Hayashi, K., Ito, O. (2009). Measurement of ammonia volatilization from flooded paddy fields in Vietnam. Soil Science and Plant Nutrition, 55, 793-799. doi: 10.1111/j.1747-0765.2009.00419.x.

Ye, Y. S., Liang, X. Q., Chen, Y. X., Liu, J., Gu, J. T., Guo, R., Li, L. (2013). Alternate wetting and drying irrigation and controlled-release nitrogen fertilizer in late-season rice: Effects on dry matter accumulation, yield, water and nitrogen use. Field Crops Res., $144,212-224$.

Yi, C., Xu, T., Sheng-Mao, W., Chun-Yan, Jia-Yu, W. (2010). Contribution of different $\mathrm{N}$ sources to crop $\mathrm{N}$ nutrition in a Chinese rice field. Pedosphere, 20(2), 198-208.

Zhang, Y., Dore, A. J., Ma, L., Liu, X. J., Ma, W. Q., Cape, J. N., Zhang, F. S. (2010). Agricultural ammonia emissions inventory and spatial distribution in the North China Plain. Environ. Pollut., 158, 490-501.

Zhang, H., Li, H. W., Yuan, L. M., Wang, Z. Q., Yang, J. C., Zhang, J. H. (2012). Post-anthesis alternate wetting and moderate soil drying enhances activities of key enzymes in-sucrose-to-starch conversion in inferior spikelets of rice. J. Exp. Bot., 63(1), 215. According 